\title{
Survival of Juvenile Acer grandidentatum Nutt. (Bigtooth Maple, Aceraceae) in Central Texas Woodlands
}

\author{
O. W. Van Auken ${ }^{*}$, D. L. Taylor ${ }^{2}$ \\ ${ }^{1}$ Department of Environmental Science and Ecology, University of Texas at San Antonio, San Antonio, Texas, USA \\ ${ }^{2}$ Cisebsi Ltd. Co., Fair Oaks Ranch, Texas, USA \\ Email: *oscar.vanauken@gmail.com
}

How to cite this paper: Van Auken, O.W. and Taylor, D.L. (2020) Survival of Juvenile Acer grandidentatum Nutt. (Bigtooth Maple, Aceraceae) in Central Texas Woodlands. American Journal of Plant Sciences, 11, 413-425.

https://doi.org/10.4236/ajps.2020.113030

Received: February 5, 2020

Accepted: March 23, 2020

Published: March 26, 2020

Copyright $\odot 2020$ by author(s) and Scientific Research Publishing Inc. This work is licensed under the Creative Commons Attribution International License (CC BY 4.0).

http://creativecommons.org/licenses/by/4.0/

\begin{abstract}
Populations of Acer grandidentatum Nutt. (Bigtooth maple, Aceraceae $=$ Sapindaceae) in central Texas are mostly found in isolated, deep, relatively remote, limestone canyons. Acer grandidentatum is found with a few other mostly deciduous species. Recruitment of juveniles has been reported to be lacking. One population of $A$. grandidentatum juveniles was found in a limestone canyon in a State Natural Area in Central Texas. Fifty juveniles were located. Wire enclosures were placed around half of the seedlings with half left in the open. In an adjacent canyon, 50 juvenile seedlings were planted in a similar habitat with adult $A$. grandidentatum trees nearby. Half were in enclosures and half in the open. Plant survival was followed for four growing seasons until November 2019. At the end of that time when survivals were compared between plants in enclosures and those in the open in both canyon communities, there was a significant difference in survival in both communities $\left(\chi^{2}, P<0.001\right)$. Survival in the planted population in enclosures was $92 \%$ with $52 \%$ in the open. In the natural population in enclosures $68 \%$ survived, with $32 \%$ survivals in the open. When population extinction was compared, extinction for planted juveniles in enclosures using linear regression was 60.5 yrs and it was $11.9 \mathrm{yrs}$ in the open. For native juveniles, it was $12.6 \mathrm{yrs}$ in enclosures and 5.9 yrs in the open. The cause of most mortalities in the open seemed to be herbivory by white-tailed deer (Odocoleus virginianus).
\end{abstract}

\section{Keywords}

Survival, Mortality, Populations, Edwards Plateau, Rare Plants, Seedlings, Woodlands, Dynamics

\section{Introduction}

Dynamics of woodland or forest communities have been difficult to understand 
[1] [2]. Populations or communities of relic or isolated woody plants are more difficult to understand than herbaceous communities because of the long lives of the woody species and they are usually isolated with low density [3] [4]. In private property states, trying to determine species or community dynamics is more difficult, because with changing ownership, management changes and temporal effects are difficult to follow especially with long-lived species [5]. In addition to recent changing management strategies, long term changes in North American plant communities have been occurring at least over the last 20,000 years caused by warming temperatures, glacial re-treat [6], the presence of Native Americans [7] and the arrival of the Europeans and their animals [8]. Population dynamics cannot be understood unless light, nutrient and water levels are understood in addition to effects of competitors, herbivores and carnivores [9] [10] [11] [12].

Changes in species composition have been reported for many North American woodland and forest communities and are widespread and species independent including lack of replacement of mature species [11] [13] [14] [15]. Lack of replacement is not caused by lack of germination but occurs at later growth stages and was not a problem prior to Europeans arriving in North America [16] [17].

The topic of the current study, $A$. grandidentatum, is widespread in the mountains in New Mexico, western Texas and other mountains of the western United States [18] [19] [20] [21]. It is also found in central Texas and southwestern Oklahoma [20] [21] [22]. Anecdotal reports suggest populations of $A$. grandidentatum in central Texas are not being replaced [23] [24]. There is one limited experiment showing complete loss of non-protected A. grandidentatum juveniles due to large animal herbivory in one growing season [12]. A structural study demonstrated that $A$. grandidentatum populations had inverse quadratic size distributions with few juveniles and very little possible recruitment over the 20 years prior to the study [25]. Acer grandidentatum has high seed germination, grows best at medium light levels and can carry out $\mathrm{CO}_{2}$ uptake at low light levels (shade) [12]. However, we have not found other specific studies concerning population dynamics of $A$. grandidentatum.

There are studies that have shown lack of recruitment of the mature forest trees in eastern North America [13] [26] [27] [28], in the mountains of western North America [11] [29] [30], and in woodlands of Texas and the mountains of southwestern North America [1] [10] [12] [15] [31]-[36].

Lack of tree recruitment in eastern North America has been caused by high density of Odocoileus virginianus (white-tailed deer) [13] [28] [37] [38]. In central Texas, the cause appears to be the same, browsing by large populations of $O$. virginianus [12] [31] [39] [40]. High abundance and browsing of Cervus elaphus (Rocky Mountain Elk, Red deer) in Yellowstone and other western national parks has caused a lack of recruitment of woody seedlings of other species in these areas [11] [29] [30] [41]. Lack of recruitment in most populations of $A$. grandidentatum is not known nor is it known if this occurred in the past. 
The purpose of this study was to examine effects of large animal herbivory on the mortality and survival of $A$. grandidentatum juveniles in native plant communities in central Texas.

\section{Materials \& Methods}

Site description. This venture was carried out on the 1520 ha (= 3757 ac) Albert and Bessie Kronkosky State Natural Area which is in Kendall and Bandera counties, central Texas from April 2016 through November 2019. This area is in the Edwards Plateau Physiographic region of central Texas (Figure 1, approximately $29^{\circ} 44^{\prime} 25^{\prime \prime} \mathrm{N}, 98^{\circ} 50^{\prime} 18^{\prime \prime} \mathrm{W}$ ) [42]. The study locations were specifically in the "Tin Cup Canyon" and the canyon that is the source of water for Bessie's pond [43]. For many years, domestic grazing was the industry of this area of central Texas, then in 1998 a $2.4 \mathrm{~m}$ high fence was erected and domestic grazing was stopped on the former ranch (Personal communication with James Rice).

Elevation of the study area is approximately $484-614 \mathrm{~m}$ a. m. s. The A. grandidentatum communities, where the study was carried out, have moderately deep calcareous silty clay soil, Mollisol overlying limestone bedrock [44]. Acer grandidentatum had the highest density and relative density (52\%) of overstory plants in the canyon communities [25]. Other overstory species found in the canyon communities in descending order of relative density included Juniperus ashei (a gymnosperm), Prunus serotina (black cherry), Quercus laceyi (Lacey oak), Q. buckleyi (Texas red oak), Tilia caroliniana (Carolina basswood), and a few other mostly deciduous species. The approximate mean annual temperature in the study area is $18.3^{\circ} \mathrm{C}$, and ranges from near $0.7^{\circ} \mathrm{C}$ in January to $34.1^{\circ} \mathrm{C}$ in

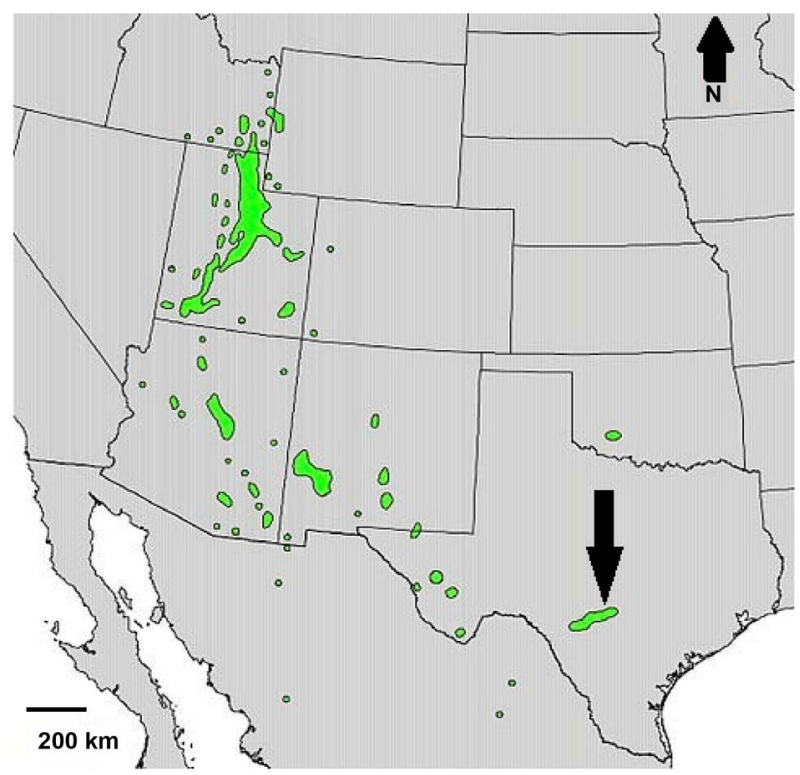

Figure 1. Maps showing Texas within the United States and the approximate location of the study site (lower black arrow) and the distribution of Acer grandidentatum in Texas, New Mexico, Oklahoma and parts of the western United States. 
August, but is highly variable. The mean annual precipitation is extremely variable as well, but roughly $72.4 \mathrm{~cm} / \mathrm{yr}$ with very little in July and August with May and September being wettest [45].

Plants studied. In spring 2016 two areas of the ABK Natural Area were surveyed for newly emerged $A$. grandidentatum Nutt (bigtooth maple, Aceraceae = Sapindaceae) [21], seedlings. The two areas were called Tin Cup Canyon and the canyon that is the source of water for Bessie's Pond. A number of newly emerged A. grandidentatum seedlings were found in the Tin Cup Canyon. They could be told as newly emerged seedlings because the two cotyledons $(1-2 \mathrm{~cm}$ long, narrow, green, first leaf like structures) were still attached to the stem. Each was flagged and a numbered tag was placed in the soil $2-4 \mathrm{~cm}$ from the base of the stem. The bottom of the canyon, near adult $A$. grandidentatum trees, was searched until 50 seedlings were found. The Bessie's Pond Canyon was also searched for seedlings, but unfortunately few were found. We obtained 65 newly emerged seedlings from a local grower. The seedlings were from seed locally collected the previous fall and germinated over the previous winter. These seedlings were in five centimeter peat cups, were approximately seven $\mathrm{cm}$ tall with 2 - 6 new leaves. Seedlings were planted in $5-7 \mathrm{~cm}$ deep holes dug in the soil in the $A$. grandidentatum community, in the canyon upstream from Bessie's Pond in the ABK natural area. The seedlings were flagged, tagged and watered immediately and for the next four weeks before the start of the experiment.

Enclosures and Analyses. While the plants were establishing and growing, a series of 50 "rabbit wire", 19-gauge, $1.27 \mathrm{~cm}^{2}$ galvanized hardware cloth enclosures were constructed. The enclosures were $12 \mathrm{~cm}$ in diameter, $48 \mathrm{~cm}$ in height and covered with a cap of the same type of wire. The enclosures were transported to the two field sites and then one enclosure was placed over each one of the 25 seedlings to be part of the enclosure treatment. Two seedlings were selected in relatively close proximity and one was haphazardly chosen to be enclosed. The enclosures were next secured to the ground surface using three 60 $\mathrm{cm}$ long, $1.5 \mathrm{~cm}$ diameter iron rebars pounded into the ground. The plants in the Tin Cup Canyon were inspected once per week for the first month of the study. The plants in Bessie's Pond Canyon were inspected and watered once a week for the first month of the study to insure they had survived the transplant. Next, the plants were inspected approximately once per month to determine survival. For the next three years the plants were examined intermittently and approximately once per month, except during winter when they were not checked or examined for survival or mortality. In several cases a plant was considered dead (no leaves) early in the growing season but found alive (with leaves) at a later check. When this occurred, the number of mortalities previously recorded was adjusted. The data was summarized in the fall of 2019, but flags, tags and cages were left in place.

Total survival in both locations and both treatments were statistically compared using a $\chi^{2}$ analysis. Seedling survival in time was examined using a linear 
regression in spreadsheet software, but there was considerable variability. Consequentially, the data for both sites and treatments were summed over each year and reanalyzed. Annual survival of the seedlings in the four treatments was evaluated for temporal changes with Kaplan-Meier survival analysis [34] [46]. Subsequently, time of population extinction for each treatment population was estimated using simple linear regression analyses.

\section{Results}

The number of survivors and mortalities for the plants transplanted into the Bessie's Pond area are shown (Table 1), with the percent survivors, that can also be seen in Figure 2. There were significantly more dead plants in the open treatment compared to those in the enclosure treatment $\left(\chi^{2}, p<0.001\right.$, Table 1$)$. One plant in the enclosure died (4\%) in the first 17 weeks of the experiment $v s$. six mortalities in the open treatment (24\%). Another mortality was found in the enclosure over the remainder of the experiment (8\%) with 23 surviving (92\%). There were six more mortalities in the open treatment over the remainder of the experiment for a total of 12 mortalities in the open (48\%) or 13 survivors (52\%) (Table 1, Figure 2).

The number of seedling survivors and mortalities for the natural germinated seedlings found in the Tin Cup area are presented (Table 1, Figure 3). Three seedlings died in the open treatment in the first growing season of the experiment and two plants died in enclosures during this same time period. Eight plants in the enclosures were dead (32\%) or 17 survivors (68\%) at the end of the experiment versus 17 plants dead in the open treatment (68\%) with 8 survivors (32\%) (Table 1). Most of the mortalities in the open occurred in the last 2 years of the experiment (Figure 3 ). There were significantly more dead plants in the open treatment compared to those in the enclosure treatment $\left(\chi^{2}, p<0.001\right.$, Table 1).

Table 1. Number and percent live or dead Acer grandidatum juveniles that were planted or found in two separate natural deciduous woodland community after four years. Half were placed in enclosures and half were left in the open. There were 50 plants in each planting area with 25 in each enclosure or open treatment. The ${ }^{\star}$ indicates significant $\chi^{2}$ differences $(P<0.001)$ between the number of dead plants in the enclosure and the open treatments in both the natural grown and the planted individuals after four years.

\begin{tabular}{ccccc}
\hline & PLANTED & \multicolumn{3}{c}{ NATURAL } \\
\cline { 2 - 5 } & ENCLOSURE & OPEN & ENCLOSURE & OPEN \\
\hline LIVE & 23 & 13 & 17 & 8 \\
DEAD & $2^{*}$ & 12 & $8^{*}$ & 17 \\
TOTAL & 25 & 25 & 25 & 25 \\
$\%$ LIVE & 92 & 52 & 68 & 32 \\
$\%$ DEAD & 8 & 48 & 32 & 68 \\
TOTAL & 100 & 100 & 100 & 100 \\
\hline
\end{tabular}




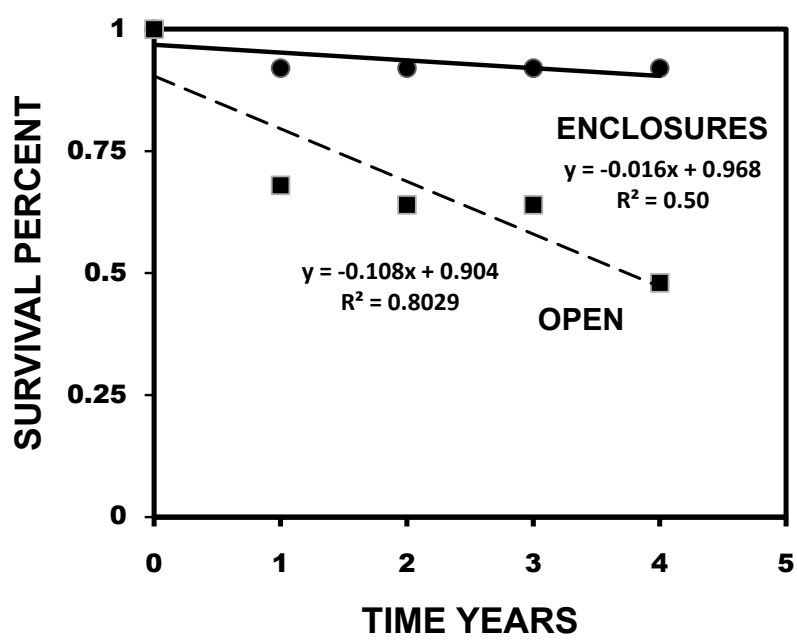

Figure 2. Plots showing survival distribution functions (Kaplan-Meier) of the percent Acer grandidentatum seedlings surviving each year of the study. Seedlings were located in the Bessie's Pond Canyon and transplanted there at the beginning of the study and grown there for the four-year study starting in 2016 through 2019. Filled or solid circles and solid line for seedlings in enclosures and solid or filled squares and dashed line is for seedlings in the open, with no enclosures. Equations are for linear best fit models.

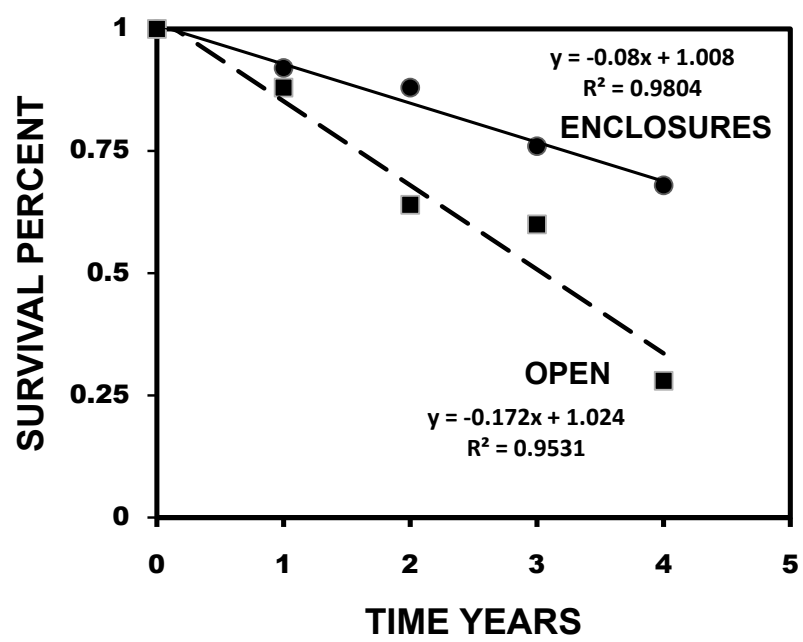

Figure 3. Plots showing survival distribution functions (Kaplan-Meier) of the percent Acer grandidentatum seedlings surviving each year of the study. Seedlings were located in the Tin Cup Canyon and naturally germinated and grown there for the four-year study starting in 2016 through 2019. Filled or solid circles and solid line for seedlings in enclosures and solid or filled squares and dashed lines are for seedlings in the open, with no enclosures. Equations are for linear best fit models.

Results were re-examined looking at percent survival per year. Results presented are best fit inverse linear plots (Table 2). Linear regressions were used to estimate population extinctions (Table 2 ). The regression equation and $\mathrm{R}^{2}$ values 
Table 2. Expected population extinction time, time to $100 \%$ mortality, predicted from simple linear regressions of each experimental treatment and not forcing the data through zero. Equations and $\mathrm{R}^{2}$ values are presented below the extinction time estimates.

\begin{tabular}{|c|c|c|c|c|}
\hline & POPULATION & TREATMENT & & \\
\hline & PLANTED & & NATURAL & \\
\hline TIME & ENCLOSURE* & OPEN $^{\star *}$ & ENCLOSURE $^{\star * *}$ & $\mathrm{OPEN}^{* * *}$ \\
\hline YEARS & 60.5 & 11.9 & 12.6 & 5.9 \\
\hline
\end{tabular}

are presented (Table 2). For the planted seedling population in enclosures, extinction time for the population was $60.5 \mathrm{yrs}$. while those in the open had population extinction times or 11.9 yrs. Seedlings protected by cages and planted survived 5.1 times longer than those planted in the open.

For the natural populations found in the Tin Cup Canyon, those in enclosures had an expected extinction of $12.6 \mathrm{yrs}$. and those plants in the open had an expected extinction of 5.9 yrs. (Table 2). Seedlings planted in the open survived $46.8 \%$ as long as those in enclosures, or those protected from herbivory. Plants in enclosures survived 2.14 times longer than those in the open. Planted seedlings in the open survived almost twice as long as natural occurring seedlings in the open (Table 2).

\section{Discussion}

Recruitment of juveniles for a number of woody species has diminished in woodlands and forests in many parts of North America [13] [15] [35] [38] [41]. In central Texas, the same phenomenon is happening, no recruitment into adult populations of deciduous species [25] [31] [36] [47]. Juveniles or small plants appear to be inhibited or growth suppressed and not entering the adult population. However, the basis of the mortalities in most cases is only suspected. One study showed 33\% survival of planted A. grandidentatum in enclosures for one year when compared to no survivors when plants were in the open, suggesting large animal herbivory [12]. However, the sample size was small. In another project with other species, changes in diameter were demonstrated to be associated with community succession and included high seedlings mortality [48] Acer grandidentatum populations have also been shown to have unimodal size and age distributions with a positive skew and only a very few individuals in the smallest size or age class, suggesting little or no recruitment into the mature population [25].

It seems certain that recruitment of mature community species in mature plant populations across North America has declined apparently because of large populations or various herbivores [11] [13] [15] [25] [35] [38] [41]. In the present study, excluding large animals protected many juvenile plants in enclosures from herbivory and mortality for over $4 \mathrm{yr}$. Overall, there were 10/50 mor- 
talities in enclosures (20\%), compared to $30 / 50$ in the open or $60 \%$. Looking at survival, $40 / 50$ or $80 \%$ survived in enclosures while $20 / 50$ or $40 \%$ survived in the open.

The juveniles in the enclosures had a high survival and low rate of mortality for the entire study period. The high juvenile survival in the current study, compared to previous studies, is probably due to the lower density of the large herbivores in the natural area studied. In other places in central Texas, the density of Odocoleus virginianus (white-tailed deer) was quite high at 1 deer /5 ha which is as high or higher than anywhere else in North America [49] [50] [51]. In other areas of western North America, the density of Cervus elaphus (red deer or elk) was high causing similar problems [11]. However, in the Albert and Bessie Kronkosky State Natural Area where the present study was conducted, density of $O$. virginianus is reported as much lower, approximately 1 deer /23 ha, almost five times lower [51]. This is because of high fencing around the Natural Area as well as some removal by yearly hunting for the past 20 years (Personal communication with James Rice).

Over harvesting of $O$. virginianus in the early 1900's led to a marked decline in their population; thus, harvest (hunting) laws were put in place by the Texas State Government to be enforced by the Texas Parks and Wildlife Department [39]. This resulted in recovery of the $O$. virginianus population and the current overabundance of the population, with a concomitant decline in recruitment of many deciduous woody species including A. grandidentatum [4] [25] [31] [36] [40] [47] [52].

Complete mortality of $A$. grandidentatum in the open did not occur in the present study, although survival of juveniles in enclosures for almost four years was higher than in the open. Populations of $A$. grandidentatum juveniles survived 2 - 5 times longer when protected from herbivory compared to non-protected plants. This suggests that large animal herbivory, probably $O$. virginianus was the cause of the mortalities. This also suggests that the density of these large herbivores is very important for recruitment of juveniles into the adult population. Approximately half of the juveniles in the open survived approximately four years suggesting there may be another or other factors involved in juvenile survival and recruitment into the adult population. Climate especially amount and timing of rainfall may be the cause of mortality and lack of recruitment. Intermittent or episodic recruitment may be occurring in these A. grandidentatum populations, but this is not known.

When the age structure of several of these isolated $A$. grandidentatum populations from the $\mathrm{ABK}$ natural area were examined, they were unimodal with one major recruitment period and little evidence of repeated recruitment over approximately 400 years [25]. The major period of recruitment was approximately $1970 \pm 16$ yr. There was little indication of episodic recruitment in the summary plot for the five communities examined, but two communities could have had two fairly broad times of recruitment. When Pinus edulis (Pinon pine) communities were examined in southern Colorado, there were two types of recruit- 
ment, but the recruitment occurred over 200 - 400 years dependent on reoccurring very dry periods and reoccurring stand destroying, hot fires [53]. Another study showed the western United States, including much of Texas, is in the midst of an unprecedented, long term drought [54] that certainly could have caused limited and sporadic recruitment in some of these populations.

There doesn't appear to be enough fuel in these central Texas canyon A. grandidentatum communities to support fires, although the canyon communities are surrounded by Juniper ashei woodlands that will burn, but only when it is very dry, temperatures are high and wind speed is high (personnel observation, Kerr Wildlife Management Area). It is certainly possible that $O$. virginianus density and other undetermined factors are related causing $O$. virginianus to migrate in and out these $A$. grandidentatum communities, but while they are present, they could consume most or all of the A. grandidentatum juveniles and juveniles of most other deciduous species, resulting in episodic intervals of no recruitment of the juveniles into the mature populations.

There were other herbivores in the area of the study including various rodents, but the enclosures were capped with the same wire as the sides, thus excluding species climbing over to get to the seedlings or juveniles. Feral hogs were present in the area indicated by digging and rooting, but caged or uncaged $A$. grandidentatum plants were not disturbed. We expected survival would be an inverse exponential function as was the case for other species [34], but found inverse linear functions described survival fairly well. We used these inverse linear equations to show expected time of population extinction and showed significant differences between protected and non-protected $A$. grandidentatum juveniles, thus suggesting herbivory as the cause of most of the mortalities. However, the time to population extinction was $5.9-11.9$ yrs for populations in the open and 12.6 - $60.5 \mathrm{yrs}$ in enclosures and we think this time interval would be long enough for some of these individuals to become established and avoid the possibility of mortality by $O$. virginianus herbivory. Continued examination of temporal changes in the populations would be judicious to confirm recruitment or extinction.

\section{Acknowledgements}

We thank James Rice superintendent of the Albert and Bessie Kronkosky State Natural Area for encouragement to study isolated Acer grandidentatum populations and for supplies needed to set up the study. Both James Rice and Tom Riordan helped us with transportation needed to get to the remote study sites. Thanks also to Chen Chen Shen for help setting up the study. The authors also thank Julian Chavez for preparing the A. grandidentatum distribution map.

\section{Conflicts of Interest}

The authors declare no conflicts of interest regarding the publication of this paper. 


\section{References}

[1] Russell, F.L. and Fowler, N.L. (1999) Rarity of Oak Saplings in Savannahs and Woodlands of the Eastern Edwards Plateau, Texas. Southwestern Naturalist, 44, $31-41$.

[2] Baker, P.J., Bunyavejchewin, S., Oliver, C.D. and Ashton, P.S. (2005) Disturbance History and Historical Stand Dynamics of a Seasonal Tropical Forest in Western Thailand. Ecological Monographs, 75, 317-343. https://doi.org/10.1890/04-0488

[3] Van Auken, O.W. (1997) Species Rareness and Commonness along Spatial and Temporal Gradients. Southwestern Naturalist, 42, 369-377.

[4] Pool, J.M., Carr, W.R., Price, D.M. and Singhurst, J.R. (2007) Rare Plants of Texas. Texas A \& M Nature Guides. Texas Parks and Wildlife. Everbest Printing, Louisville.

[5] Carpenter, J. and Brandimarte, C. (2014) The Albert and Bessie Kronkosky State Natural Area: A History of Lands and People. Historic Sites and Structures Program, State Parks Division, Texas Parks and Wildlife Department.

[6] Van Devender, T.R. (1995) Desert Grassland History: Changing Climates, Evolution, Biography, and Community Dynamics. In: McClaran, M.P. and Van Devender, T.R., Eds., The Desert Grassland, University Arizona Press, Tucson.

[7] Collins, S.L. and Wallace, L.L. (1990) Fire in North American Tallgrass Prairie. University of Oklahoma Press, Norman.

[8] Inglis, J.M. (1964) A History of Vegetation on the Rio Grande Plain. Texas Parks and Wildlife Department Bulletin, 45, 1-38.

[9] Archer, S., Schimel, D.S. and Holland, E.A. (1995) Mechanisms of Shrubland Expansion: Land Use, Climate or $\mathrm{CO}_{2}$. Climate Change, 29, 91-99. https://doi.org/10.1007/BF01091640

[10] Van Auken, O.W. (2009) Causes and Consequences of Woody Plant Encroachment into Western North American Grasslands. Journal of Environmental Management, 90, 2931-2942. https://doi.org/10.1016/j.jenvman.2009.04.023

[11] Beschta, R.L., Painter, L.E., Levi, T. and Ripple, W.J. (2016) Long-Term Aspen Dynamics, Trophic Cascades, and Climate in Northern Yellowstone National Park. Canadian Journal of Forest Research, 46, 548-556. https://doi.org/10.1139/cjfr-2015-0301

[12] Nelson-Dickerson, T. and Van Auken, O.W. (2016) Survival, Growth and Recruitment of Bigtooth Maple (Acer grandidentatum) in Central Texas Relict Communities. Natural Areas Journal, 36,174-180. https://doi.org/10.3375/043.036.0209

[13] Lorimer, C.G. (1992) Causes of the Oak Regeneration Problem. In: Loftis, D.L. and McGee, C.E., Eds., Oak Regeneration: Serious Problems, Practical Recommendations, USDA Southeastern Forest Experiment Station, Knoxville, 14-40.

[14] Shumway, D.L., Abrams, M.D. and Ruffner, C.M. (2001) A 400-Year History of Fire and Oak Recruitment in an Old-Growth Oak Forest in Western Maryland, USA. Canadian Journal of Forest Research, 31, 1437-1443. https://doi.org/10.1139/x01-079

[15] Ryniker, K.A., Bush, J.K. and Van Auken, O.W. (2006) Structure of Quercus gambelii Communities in the Lincoln National Forest, New Mexico, USA. Forest Ecology and Management, 233, 69-77. https://doi.org/10.1016/j.foreco.2006.06.008

[16] Mensing, S.A. (1992) The Impact of European Settlement on Blue Oak (Quercus douglasii) Regeneration and Recruitment in the Tehachapi Mountains, California. 
Madronõ, 39, 36-46.

[17] Abrams, M.D., Orwig, D.A. and Demeo, T.E. (1995) Dendroecological Analysis of Successional Dynamics for a Presettlement-Origin White-Pine-Mixed-Oak Forest in the Southern Appalachians, USA. Journal of Ecology, 83, 133-143. https://doi.org/10.2307/2261156

[18] Hanks, J.P. and Dick-Peddie, W.A. (1974) Vegetation Patterns of the White Mountains, New Mexico. Southwestern Naturalist, 18, 371-382. https://doi.org/10.2307/3670295

[19] Alexander, B.G., Ronco, F., Fitzhugh, E.L. and Ludwig, J.A. (1984) A Classification of Forest Habitat Types of the Lincoln National Forest, New Mexico. USDA Forest Service, Rocky Mountain Forest and Range Experiment Station, General Technical Report RM-104, Fort Collins. https://doi.org/10.5962/bhl.title.99516

[20] Tollefson, J.E. (2006) Acer grandidentatum. Fire Effects Information System, USDA, Forest Service, Rocky Mountain Research Station, Fire Sciences Laboratory. http://www.fs.fed.us/database/feis

[21] USDA NRCS (2019) Plants Database, USDA Natural Resources Conservation Service. http://plants.usda.gov/java/profile?symbol

[22] Correll, D.S. and Johnston, M.C. (1979) Manual of the Vascular Plants of Texas. Texas Research Foundation, Renner.

[23] BCNPSOT (2010) Bigtooth Maples for Boerne, TX. http://npsot.org/wp/boerne/maples-for-boerne

[24] Heidemann, R.E. (2011) Lost Maples State Natural Area. Handbook of Texas Online. http://www.tshaonline.org/handbook/online/articles/gil01

[25] Van Auken, O.W., Taylor, D.L., Shen, C. and Bush, J.K. (2017) Structure of Isolated Acer grandidentatum (Bigtooth Maple) Communities and Potential Population Changes. American Journal of Plant Science, 8, 1368-1387.

[26] Lorimer, C.G. and Krug, A.G. (1983) Diameter Distributions in Even-Aged Stands of Shade-Tolerant and Midtolerant Tree Species. American Midland Naturalist, 109, 331-345. https://doi.org/10.2307/2425414

[27] Loftis, D.L. and McGee, C.E. (1992) Oak Regeneration: Serious Problems, Practical Recommendations. USDA Southeastern Forest Experiment Station, Knoxville. https://doi.org/10.2737/SE-GTR-84

[28] Abrams, M.D. (2003) Where Has All the White Oak Gone? BioScience, 53, 927-939. https://doi.org/10.1641/0006-3568(2003)053[0927:WHATWO]2.0.CO;2

[29] Ripple, W.J., Beschta, R.L. and Painter, L.E. (2015) Trophic Cascades from Wolves to Alders in Yellowstone. Forest Ecology and Management, 354, 254-260. https://doi.org/10.1016/j.foreco.2015.06.007

[30] Beschta, R.L. and Ripple, W.J. (2016) Riparian Vegetation Recovery in Yellowstone: Two Decades after Wolf Reintroduction. Biological Conservation, 198, 93-103. https://doi.org/10.1016/j.biocon.2016.03.031

[31] Van Auken, O.W. (1988) Woody Vegetation of the Southeastern Escarpment and Plateau. In: Amos, B.B. and Gehlbach, F.R., Eds., Edwards Plateau Vegetation: Plant Ecological Studies in Central Texas, Baylor University Press, Waco, 43-55.

[32] Van Auken, O.W. (1993) Size Distribution Patterns and Potential Population Change of Some Dominant Woody Species of the Edwards Plateau Region of Texas. Texas Journal of Science, 45, 199-209.

[33] Van Auken, O.W. (2000) Shrub Invasions of Semiarid Grasslands. Annual Review of Ecology and Systematics, 31, 197-216. 
https://doi.org/10.1146/annurev.ecolsys.31.1.197

[34] Van Auken, O.W., Jackson, J.T. and Jurena, P.N. (2004) Survival and Growth of Juniperus Seedlings in Juniperus Woodlands. Plant Ecology, 175, 245-257.

https://doi.org/10.1007/s11258-005-0022-Z

[35] Van Auken, O.W., Bush, J.K., Richter, F.A. and Karges, J. (2007) Structure of Isolated Populations of Populus tremuloides (Quaking Aspen) in the Davis Mountains of Far-West Texas. Natural Areas Journal, 27, 302-312. https://doi.org/10.3375/0885-8608(2007)27[302:SOIPOP]2.0.CO;2

[36] Russell, F.L. and Fowler, N.L. (2002) Failure of Adult Recruitment in Quercus buckleyi Populations on the Eastern Edwards Plateau, Texas. American Midland Naturalist, 148, 201-217. https://doi.org/10.1674/0003-0031(2002)148[0201:FOARIQ]2.0.CO;2

[37] Kain, M., Battaglia, L., Royo, A. and Carson, W.P. (2011) Over-Browsing in Pennsylvania Creates a Depauperate Forest Dominated by an Understory Tree: Results from a 60-Year-Old Deer Exclosure. Journal of the Torrey Botanical Society, 138, 322-326. https://doi.org/10.3159/TORREY-D-11-00018.1

[38] Abrams, M.D. and Johnson, S.E. (2012) Long-Term Impacts of Deer Exclosures on Mixed-Oak Forest Composition at the Valley Forge National Historical Park, Pennsylvania, USA. Journal of the Torrey Botanical Society, 139, 167-180. https://doi.org/10.3159/TORREY-D-11-00075.1

[39] Doughty, R.W. (1983) Wildlife and Man in Texas: Environmental Change and Conservation. Texas A\&M University Press, College Station.

[40] Russell, F.L. and Fowler, N.L. (2004) Effects of White-Tailed Deer on Population Dynamics of Acorns, Seedlings, and Saplings of Quercus buckleyi. Plant Ecology, 173, 59-72. https://doi.org/10.1023/B:VEGE.0000026329.47461.99

[41] Beschta, R.L. and Ripple, W.J. (2009) Large Predators and Trophic Cascades in Terrestrial Ecosystems in the Western United States. Biological Conservation, 142, 2401-2414. https://doi.org/10.1016/j.biocon.2009.06.015

[42] Van Auken, O.W. (2018) Ecology of Plant Communities of South-Central Texas. Scientific Research Publishing, Wuhan. http://www.scirp.org

[43] Van Auken, O.W., Taylor, D.L. and Shen, C. (2016) Diameter Growth of Acer grandidentatum (Bigtooth Maple) in Isolated Central Texas Populations. Phytologia, 98, 232-240.

[44] Hensell, J.L., Dittmar, G.W. and Taylor, F. (1977) Soil Survey of Bandera County, Texas. USDA Soil Conservation Service, Washington DC.

[45] World Climate (2011) Climate Data for $29 \mathrm{~N} 98 \mathrm{~W}$. http://www.worldclimate.com/cgi-bin/grid.pl?gr=N29W099

[46] Allison, P.O. (1995) Survival Analysis Using SAS System: A Practical Guide. SAS Institute, Cary.

[47] Bush, J.K. and Van Auken, O.W. (1986) Light Requirements of Acacia smallii and Celtis laevigata in Relation to Secondary Succession. American Midland Naturalist, 115, 118-122. https://doi.org/10.2307/2425841

[48] Knox, R.G., Peet, R.K. and Christensen, N.L. (1989) Population Dynamics in Loblolly Pine Stands: Changes in Skewness and Size Inequality. Ecology, 70, 1153-1167. https://doi.org/10.2307/1941383

[49] Adams, K.P. and Ross, M. (2015) QDMA's Whitetail Report. Quality Deer Management Association, Bogart, 1-67.

[50] Fulbright, T.E. and Ortega, J.A. (2008) White-Tailed Deer Habitat: Ecology and 
Management on Rangelands. Texas A\&M University Press, College Station.

[51] Makar, V. (2017) Estimating White-Tailed Deer Abundance within Albert and Bessie Kronkosky State Natural Area. Thesis, University of Texas, San Antonio.

[52] Nelson-Dickerson, T. and Van Auken, O.W. (2017) Seedling Growth and Photosynthesis of Acer grandidentatum (Bigtooth Maple, Sapindaceae) from Isolated Central Texas Populations. Phytologia, 99, 11-21.

[53] Floyd, M.L., Hanna, D.D. and Romme, W.H. (2004) Historical and Recent Fire Regimes in Pinion-Juniper Woodlands on Mesa Verde, Colorado, USA. Forest Ecology and Management, 198, 269-289. https://doi.org/10.1016/j.foreco.2004.04.006

[54] Cook, E.R., Woodhouse, C.A., Eakin, C.M., Meko, D.M. and Stahle, D.W. (2004) Long-Term Aridity Changes in the Western United States. Science, 306, 1015-1018. https://doi.org/10.1126/science.1102586 